\title{
MOBILITIES AND MORALITIES OF DOMESTIC WORK IN INDONESIAN CITIES
}

\author{
David Jordhus-Lier and Debbie Prabawati
}

\section{Introduction}

Domestic workers constitute a significant part of the global workforce, but are seldom acknowledged as such. The experience of being a domestic worker and the role these workers take up in the societies in which they work is spatially variegated. While domestic work is always embedded in the micro-geographies of the household, the global domestic labour force is highly mobile and many, often young women, cross continents to work for other families. Domestic workers tend to migrate to urban labour markets in search of employment, but often find themselves culturally marginalised in foreign cities. This is why mobility and urban citizenship both represent key concepts in which to understand domestic workers as subjects.

Based on recent research on domestic workers in Indonesian cities, this chapter will attempt to highlight a set of dynamics that speaks to the mobilities of domestic work but in ways that have received little focus in the literature. Our aim is threefold. First, we want to focus on migrant workers who do not cross a national border. Despite the magnitude of this group, most likely more than 10 million workers in Indonesia alone, internal domestic workers have somehow fallen off the radar of the human geography discipline. Second, we want to add nuance to the understanding of the urban for domestic work. We do so by looking at cities as senders, transit ports and destinations for domestic workers and ask how this informs the politics of domestic work in the city. Third, we pay attention to other groups of subjects constitutive of domestic work, particularly employers and recruitment agents, and discuss how their variegated mobilities shape the ability for domestic workers to claim citizenship.

The chapter will be start out with a brief review of relevant academic scholarship on domestic work, with a particular focus on how this literature has framed domestic worker mobilities, on the one hand, and the role of the urban, on the other. We will describe two cases drawn from a comparative research project on citizenship and domestic worker organisation in urban Indonesia, and discuss what these findings tell us about the possibilities for the political organisation of domestic workers in the country. 


\section{Global geographies of domestic work}

There is a significant number of academic journal articles and book publications on Indonesian domestic workers working abroad (e.g. Silvey 2004; Yeoh \& Huang 1998; Yeoh, Huang, \& Gonzalez III 1999), which place themselves in a broader academic literature on the transnational politics of migrant domestic labour (Anderson 2000; Bapat 2014; Chin 2003; Pratt 1999). In addition, international organisations such as ILO, Human Rights Watch and Amnesty are important actors in mapping the extent and nature of domestic work worldwide. Because of the informal nature of most domestic work, and the often irregular practices of migration, much of this information is based on estimates.

Domestic workers represent a sizable workforce globally, estimated at 52.6 million workers in 2010, of which 83 per cent are female and a significant proportion under the legal working age (ILO 2013). This workforce is also becoming increasingly mobile, to the point where the demand for domestic workers is named as "the main reason for the mass migration of women from the southern hemisphere to cities in the North" by the ILO (2010: 9). The South-to-North notion is too simplistic, however, and human geographers have been instrumental in mapping and understanding particular migrant routes and their social implications, including research on Indonesian workers travelling to the Middle East (Silvey 2006), the experiences of domestic workers in Asian megacities such as Hong Kong and Singapore (Yeoh \& Huang 1998), and of Filipino workers taking part in the Live-In Caregiver Program of the Canadian government (England \& Stiell 1997; Pratt 1999). The socio-geographical implications of domestic worker migration are vast. Many researchers have justifiably taken a problem-oriented approach, focusing on the forced or unforced isolation of migrant workers in private homes, the stretching of nuclear families who sees their mother disappearing for years (Pratt 2012).

Others have chosen to emphasise narratives of agency and opportunity, such as Williams' (2007) study of travelling women on ships travelling from Eastern Indonesia, many of which were poor domestic workers whose mobility enabled them to renegotiate their identities and class status. The role played by remittances also serve to nuance our understanding of domestic work migration, as money sent home to families and regional economies in sending states. Whereas India, Mexico and the Philippines might be the top recipients of remittances, the Eastern regions of Indonesia can arguably claim another record - having the highest dependency level on remittances for family income (IRIN News 2009). ${ }^{1}$ 
Despite the relatively rich literature on domestic workers in the human geography discipline and beyond, we would argue that the geographies of domestic work still suffer from certain biases. Thus far, the academic treatment of domestic worker mobility has mainly focused on those who cross national borders. This bias invokes a moral geography wherein poor countries send domestic workers to rich countries, where they are being treated in unfair ways mainly due to their lack of legal citizenship status. This moral geography is mirrored in realpolitik, for instance in the occasionally strained diplomatic relations between sending and receiving countries, such as Indonesia and Malaysia. ${ }^{2}$ However, millions of domestic workers also become migrants within their own countries, and this form of migration, like international migration, is also shaped by state policies and discourses, invokes yet other moral geographies which complicate the categories of sending and receiving states. Another side effect of this bias is that it tends to ascertain the role of visitor, or foreigner, to the domestic workers. They are the ones who traverse space in search of happiness, but often finding themselves 'out of place' in their work destination - in contrast to the employers who hire them. As we will show, this is not always the case.

Social scientists across disciplines have shown interest in how lack of legal citizenship circumscribes migrants' opportunities and segments labour markets for workers in precarious employment. This is what Goldring and Landolt (2011: 337-338) have labelled the workcitizenship matrix, in which a migrants" "shift to a more secure legal status may not necessarily be accompanied by a reduction in job precarity". This allows substantial inequalities to persist and deepen, both internal to each national economy and at a global scale, leading to what Castles (2011) has termed 'new hierarchies of citizenship'. Domestic workers with college degrees leaving their country of origin to serve middle-class or elite households in megacities across the world epitomises these emerging hierarchies. Relative deterioration of class status can be painful, as migrant domestic workers find it difficult to recover previous occupational identities in their country of residence (Pratt 1999). Moreover, the mere fact that low-skilled and poor labour migrants lack citizenship in the country of work, makes them far easier to exploit (Castles 2011)

If we are to become more sensitive towards the intra-national migration of domestic workers, and how this also reconfigures geographies of citizenship, we need to adopt a broader notion of the citizenship concept itself. For many internal work migrants, the journey from the countryside to the city has substantial implications on their social inclusion and access to rights, legally and in practice. While the civil and political rights they are granted as citizens of a 
nation-state like Indonesia might remain intact, the rights of migrant domestic workers are likely to remain unsubstantiated unless they are actively acknowledged in the households where they work, and unless this large group of workers is acknowledged in the political community of the city. In short, we have to shift our focus from a more legalistic notion of citizenship to one which is sensitive to "the process of political engagement between diverse groups and individuals" in urban societies, to cite Painter's (2005: 7) definition of urban citizenship. Suffering from low social status and lacking regulation, domestic workers are typically among the most low-paid workers in highly unequal cities. Hence, they are firmly placed at one end of the differentiated urban citizenship that arise as a result of the coming together of two groups in many Asian cities: "the executive transnational elite in their protected communities of upmarket housing [and] migrant workers in dormitories or peripheral or inner city ghettos" (Forrest 2008: 296). For workers who venture outside the household in which they work, cities are also public spaces which they have to negotiate as gendered and racialised subjects (Yeoh $\&$ Huang 1998). But while they might experience stigma and discrimination from employers and agents (Chin 1997), urban spaces are also sites of play and leisure where domestic workers can meet fellow expatriates from their home region (Williams 2007: 162).

Our research on organising domestic workers in Indonesian cities also reveals a more complex role of the urban in these migration patterns. In general, geographers have mainly portrayed cities as representing destinations for migrating domestic workers. True, multicultural world metropoles such as Toronto, Singapore and Hong Kong do offer international migrant opportunities of work in segmented labour markets. Such cities are indeed key destinations for female work migrants, not only due to their size, but due to their proportionally high levels of working middle-class women, creating a demand for paid domestic work (England \& Stiell 1997). The paradoxical geographies of migrating domestic workers is well-formulated by Williams:

"[D]omestic workers cross the marginality of the region, locating themselves physically at the centre of global cities. There in the centre, they become marginal in their roles as domestics, while at the same time they occupy a central position in the family income generating activities at home on the margin" (Williams 2007: 176)

But cities are not only attractive destination labour markets. They should also be acknowledged as key nodes in more complex mobility networks of domestic workers. They are transit ports and they play an important coordinating function in sending regions. Often do they play several of these roles at once in an urban hierarchy constituting a global labour market ladder of 
domestic work. In what follows, we will show that these different roles lead to contradictory discourses in particular cities, accommodating multiple moral geographies of work and exploitation.

\section{Domestic work in Indonesian cities}

In contrast to the international literature discussed above, academic scholarship on domestic workers working in Indonesia is very sparse, and mostly outside the human geography discipline. In recent years, international multilateral organisations have become engaged in the issue through campaigns and advocacy work. These tend to focus on the abject working conditions, widespread use of child labour and forced labour, and the abuse many domestic workers suffer from (Sheppard 2009), as well as the lack of legal protection (ILO 2013). The attention of these actors have highlighted the apparent hypocrisy of the Indonesian government, being a vocal critic of the maltreatment domestic workers receive overseas without matching this concern with "an equally strong commitment to protecting domestic workers at home" (ILO 2006: 39).

There are long, historical continuities in the use of domestic work in Indonesia. Weix (2000) portrays Indonesian domestic workers as straddling between, on the one hand, feudal and familial employment relations and, on the other, capitalist wage work in a globalised economy. Key actors in the shift from traditional to contemporary employment practices are the recruitment agents. While domestic workers used to be recruited through kinship networks, commercial actors are increasingly performing this role in modern Indonesia. Recruitment agents might be state-licensed or unauthorised, and they perform a number of functions, from recruiting and releasing workers from their own families, to facilitating legal and illegal migrant flows, to supplying employers with domestic workers. Rudnyckyj (2004) also shows how recruitment agents discipline prospective domestic workers into subjects of modern servitude through training and skills development. Given the mobility imperatives facing Indonesian domestic workers - both those who work within and outs ide the country - some of these agents have become powerful actors vis-à-vis local authorities.

According to Jala PRT, the largest NGO network devoted to domestic worker rights in Indonesia, here are more than 10.7 million domestic workers in the country. ${ }^{3}$ Middle-class and upper working-class families across this vast country employ domestic workers. This creates a complex geography of sending regions, rural hinterland in general and Eastern Indonesian 
provinces in particular, and receiving regions, urban centres in general and the islands of Java and Sumatra in particular.

Domestic workers are also subject to the micro-geographies of the household, but in ways which differ between national contexts. In Indonesia, where workers traditionally were recruited through kinship networks, Weix (2000) argues that domestic workers express 'split subjectivities' by juggling their insider/outsider status as part of the home, but outside the family for which they work. This might set domestic workers working in Indonesia apart from Indonesians working abroad, as well as domestic work in countries such as South African or US households (see, for instance, Ally 2010; Varghese 2006), where the cultural distance between employer and employee tend to be greater. As we will show, the cultural and physical distance between employer and employee, or between public authorities and exploited workers, shape the moral geographies in question.

We have undertaken qualitative research on domestic workers and their organisations in five different Indonesian cities, including focus group research with domestic workers, interviews with policy-makers, bureaucrats and local activists and academics,. Our findings in two of these cities, a provincial capital in Eastern Indonesia (Kupang) and the national capital of Jakarta, are particularly illustrating for the argument we present here. Whereas Kupang is located in a sending region, and has no domestic worker organisations, Jakarta is the destination of hundred thousands of domestic workers who come to work for a transnational elite, and has recently seen an embryonic organisation of workers.

\section{Contrasting moral geographies of domestic work in Kupang, East Nusa Tenggara}

Kupang is the capital of the Nusa Tenggara Timur province (NTT). This Eastern province is among the poorest regions of Indonesia, and struggles with social and political problems such as illiteracy and corruption. The majority of the population are Christians, both Protestant and Catholic. Many people migrate out of the province in search of work, either to Java and others islands or abroad. Malaysia is the primary overseas destination for labour migrants, followed by Singapore and Hong Kong. While we were interested in the city of Kupang as a sending node for domestic workers to other parts of Indonesia, informants were quick to point out that Kupang acted as a transit port for domestic workers recruited in the rural areas of West Timor. On this point, both NGO activists and local government officials seemed to agree. Their opinions differed, however, on the legality of this migration and whether or not local government officials were implicated in trafficking practices or not. Some activists described 
Kupang as "the main place to exchange identity", referring to how prospective domestic workers from NTT get fake identity papers with new names and an "appropriate age". Some activists claim that local government officials have been actively involved in providing these new identities. The fact that many of the fake IDs seemed to have an address in a district of Kupang city was used as corroboration of this suspicion.

There are also two government-licensed private training centres in Kupang, where domestic worker recruits are taught how to cater for middle-class households, including English and Mandarin language training, how to use various electrical appliances and how to care for babies using dolls. These training centres are run by agents who also facilitate job placement in Hong Kong, Singapore or other Indonesian cities. In addition to these local agents, a number of recruitment agents based in Java have branches in Kupang, and engage in the recruitment of people in collaboration with government bodies.

While some of the recruitment undoubtedly is done in an orderly manner, with agents offering young women protection and sufficient preparation for their working experience outside NTT, we heard many stories of girls being sent on hazardous journeys without necessary information, resources and documentation. We also heard many stories of abuse and maltreatment of workers. Most of these stories where referred to as "human trafficking". In fact, several NGOs, government bodies and development cooperation projects were specifically devoted to the fight against human trafficking in NTT.

While the out-migration of domestic workers is an important dimension of domestic work in NTT, it is not the only one. Kupang city itself, with its 350,000 inhabitants, is also employing a significant, albeit unknown, number of domestic workers. Informants describe domestic worker employment practices in Kupang as mainly based on kinship or tribal relations. Domestic workers in Kupang typically live with their employers, and might instead of being paid fully wage-compensated perform household tasks in exchange for schooling or simply a place to live. The average domestic worker wage is estimated as lower than other regions of the country, and less than half of the regional minimum wage.

A striking observation when speaking to various informants in Kupang, was the contrasting ways in which locally-based and migrating domestic workers were described. Migrants were seen, on the one hand, as vulnerable individuals who are taking risks in pursuit of happiness, and, on the other hand, as remittance senders and therefore potentially important contributors to local economies and facilitators of social mobility for their own children. Still, when 
discussing the problems of human trafficking, informants seemed to express implicit moral judgments over those who choose to leave NTT:

"Domestic helpers should go back to Timor, who are from Timor." (Local activist 1)

"If you ask someone to work as domestic worker, if it is in Kupang, they will refuse. But if they are offered to work as domestic workers in Bali, Surabaya, or Batam, they will gladly take it. To them it means they will travel to faraway places, different places, and with an airplane." (Local activist 2)

"How should we empower them, domestic workers, so that they are not sent overseas or elsewhere here in Indonesia?" (Local activist 3)

"I said if we can protect the domestic workers [through regulation] then we will not become slaves in other countries because we appreciate them." (Local activist 4)

In some of these quotes, a problem-oriented attitude to out-migration is explicitly connected to the low wages and lack of protection of domestic workers in Kupang. But theses glimpses of reflexivity were exceptions from the norm. In most cases, and particularly when speaking to government officials, domestic worker employment cases in Kupang were depicted as unproblematic by our informants:

"So far in NTT, especially in Kupang, there have never been any problems with domestic helpers. [...] It is more a question of social control. It is the task of society to make sure workers are treated well." (Provincial government official 1)

"In principle, domestic workers in NTT are different than on Java in general, or more specifically in big cities, because usually domestic workers here are also NTT people. We rarely hire those from Java. [...] Since we are the same, and usually from the same tribe, for example Sabu people hire Sabu people, that eventually makes us treat them as our own." (Provincial government official 1)

"In general here in NTT, the workforce is not seen as a politically contested issue, but rather as an economic issue." (Local activist 5)

As an indication of the latter quote, there were neither any domestic worker organisations in the province nor any NGOs devoted to the rights of domestic workers. A representative of a women's crisis centre we spoke to, said that a few of the victims of domestic violence that sought help at the centre were domestic workers, but that she suspected this group in particular 
was under-represented, since domestic worker matters were seen as private matters in Kupang (see above quote on 'social control').

Another issue that most of our informants seemed to agree on was that paying the minimum wage to domestic workers was both unrealistic and undesirable. On this question, it became evident that government officials and middle-class activists alike where inhabiting multiple roles of interests. While they were politically involved in issues of women's rights and worker protection, they were also employers of domestic workers themselves. Hence, several informants stated that an introduction of a mandatory minimum wage would effectively drive the privilege of domestic help out of the hands of the middle class workers and civil servants who juggle their professional and household demands.

By way of summary, domestic work in Kupang is understood as contrasting moral geographies. Domestic workers who leave the region are spoken of as vulnerable victims of opportunistic agents and corrupt government officials. Domestic workers who work in Kupang, however, are portrayed as a natural part of Eastern Indonesian society, embedded in cultural practices and protected by mechanisms of social control. Perhaps this distinction is understandable (not excusable), all the time the 'wrongdoers' in the human trafficking narrative are agents, local government officials and employers elsewhere, whereas the 'wrongdoers' in the local domestic helper narrative are the ordinary citizens of Kupang.

\section{Organising domestic workers in Jakarta expat communities}

Jakarta is a very different city from Kupang, not only in its capacity as the national capital of Indonesia but also as one of the most populous metropolitan areas in the world. As Jakarta accommodates the national and regional headquarters of domestic and multinational companies, it constitutes a dynamic urban labour market which not only attracts thousands of people each year working in these companies, but also a lot of people who perform supply and support functions for these companies, for their employees and for their families. Business expats in Jakarta often arrive in the city with demanding professional commitments but without their social networks, and therefore rely on using domestic workers to perform household tasks. To satisfy this demand, poor women take up work with expat families in Jakarta - many of them are themselves migrants from rural areas of Java or other parts of Indonesia.

Among the most popular places to live for expats are the apartment blocks in South Jakarta, close to international schools and a relatively short commute from the central business district. Here, many expats tend to cluster together in residential areas, often inhabiting the same 
apartment complexes. Expats of particular nationalities also have a host of clubs and organisations to parttake in, and these ethnic networks are crucial in embedding people quickly into social life in Jakarta. Expat life can also enjoy various online communities entirely devoted to offer information, facilitate discussions and mediate sales between expats.

The same networks are also useful for recruiting household staff and coordinating their employment. Because many apartment dwellers do not require a full-time domestic worker who lives in the apartment, there is a need for coordination between different households over the same part-time staff. Informants told us of caretakers and other key people which functioned as domestic labour agents in particular apartment blocks, monitoring and managing household staff for their own ethnic community. The preference for ethnic homogeneity among expats is also projected onto their employment practices: online forums actively encourage expats to hire household staff from the same ethnic community to "maintain harmonious relationships" in the household. ${ }^{4}$

Domestic workers we spoke to told of mixed experiences with working for expats. On the one hand, expat employers were seen as paying better wages and offering more household aids relieving manual work. They are also described as demanding, and even though domestic workers in expat households were required to speak English, there were both cultural and linguistic barriers to an open communication with their employers. Workers we interview made it clear that they viewed the expats as foreigners in Jakarta, in contrast to Indonesian employers and recruiters, who were referred to as 'our people'. Some nationalities had a particularly good reputation for being good employers, mainly countries with extensive worker rights protection in their own labour markets. Still, domestic workers expressed concern that many expat employers suspended their own normative assumptions of what decent employment should look like when living in Jakarta. In one case, an employer had referred to the lack of domestic worker regulations in Indonesian law when denying his staff pension payments.

It is in these close-knit expat communities that embryonic worker organisations have started to emerge among domestic workers. Encouraged and supported by the national domestic worker network Jala PRT, organisations such as Sapulidi Domestic Workers' Union have gone from zero to a 150 members in a few years time (Gastaldi 2015). Because working for expats is seen as a good job for a domestic worker in relative terms, few workers we spoke to had thought becoming a union member before they found themselves in a difficult situation with their employer. Only when problems arise and trust is broken that the idea of seeking support or 
getting organised seemed to appear. Among the many problems domestic workers in South Jakarta told us of were unpaid wages, sexual abuse, financial penalties and harassment. Moreover, these workers were systematically denied work contracts and social security by their employers. We even were told stories of domestic workers who turned down offers of a formal contract from their employer, because they were afraid of sanctions from the employer or the police.

Workers who were involved in the early organising efforts, emphasised how the networks of the expats provided a blueprint for their own organisation:

"[T]hey talk to each other. Always. So, these Koreans have a group. And that's why I told my friend, "those Koreans have a group, why can't we domestic workers have one? Let's make an organisation!"' (Union organiser 1)

In the same way as the employers, the workers with support from the NGO network Jala PRT started using the apartment buildings as a basis for their recruitment efforts. In each apartment building, they recruit a 'community leader' who becomes in charge of representing existing members and recruiting new. This organising model is similar to how unions in the hospitality industry recruits in large hotel facilities (Gray 2004; Tufts 2007). Sapulidi organisers "map the community" of each block, and find out how and when the workers exit the house. In many ways, their organisation is built on already existing social networks in these apartment buildings. Starting out as basic exchange of information between workers working in the same workplace, the organisation now facilitates skills development like English courses and web courses.

Thanks to their close relationship with Jala PRT, Sapulidi has been able to refer workers to activists and lawyers who has settled problems members have had with their employers. This reputation has undoubtedly assisted their recruitment efforts. Given that Sapulidi organises in expat communities, the cultural distance between employers and employees arguably makes it easier for workers to hide their political activism from their employer. Sapulidi attend regular meetings, often without the employers knowing, although this is more challenging for workers living with their employers. When asked about their experiences of joining the union, members of Sapulidi were eager to express a feeling of empowerment:

"At first I was not active. But once I got problem, it made me realize that we should be together to become stronger. That's when the organization comes in handy, to help me with my case." (Domestic worker 1) 
“Thanks to this organisation, my friends now are able to stand up for themselves. We didn't have the guts before, including me." (Union organiser 1)

"Before joining this organisation it was difficult to speak, now that we have joined, everytime we meet people we speak until we realise that we have talked too much." (Domestic worker 2)

"I used to be a helper. But now I am a worker." (Domestic worker 3)

Their modest progress notwithstanding, Sapulidi and other embryonic worker organisations in Jakarta still only organise a tiny fraction of the city's workforce, and face huge difficulties in representing domestic workers effectively. An important reasons is that domestic workers are still not seen as legitimate workers in Jakartan society and, consequently, that their representative organisations are still not seen as legitimate actors in industrial relations. Hence, Sapulidi is very weakly articulated with other trade unions. In fact, trade union members in Jakarta often employ domestic workers themselves, which raises serious questions around their solidarity for Sapulidi's members. Moreover the organisation is still heavily reliant on the support of the Jala PRT activist network in order to have any media visibility or political influence. In other words, substantial urban citizenship is still a long way ahead for the domestic workers of Jakarta.

\section{Conclusion}

The importance of mobile labour for the growth of paid domestic work worldwide has already been acknowledged. But as we have tried to argue in this chapter, is this often done by ascribing relatively static and uniform roles to employers and employees, and to the cities themselves. The global mobility of labour is embedded in the urban in complex ways. Domestic workers uses cities as starting points, transit ports and work destinations. So may their employers. Each city may play multiple roles simultaneously in the demand, supply and mediation of mobile labour. In the cases of Kupang and Jakarta, this variegates how different domestic workers' rights are realised - as workers and citizens.

Domestic worker rights in Kupang seem trapped in a moral geography between those who use the city as a transit port and those who seek work there. The former group is stigmatised as risktaking, profitable and vulnerable job-seekers, but also as citizens whose well-being and protection is the moral obligation of political authorities and civil society. The latter group is rendered invisible in political life, and their exploitation is legitimised by reference to cultural practices and social code. Jakarta is, among many things, an important place of work for an 
international elite of business people. Interestingly, it is among this group of mobile workers, who themselves lack formal citizenship, that an emergent domestic workers' movement has found the most fertile ground for recruiting members. By permeating expats' own tightknit cultural communities, domestic workers have managed to build a small trade union in a hostile climate for workers.

Being subject to the atomised intimacy of the home is recognised as a key challenge for domestic workers worldwide. The socio-cultural proximity between employers and domestic employees in Indonesia is likely to create even stronger disincentives for rights-based or classbased politics. While we should be careful not to make sweeping generalisations based on the two cities presented in this article, it appears as if the physical and perceived distance that emerges with highly mobile employers, in the case of expats in Jakarta, or employees, in the case of labour migrants from Kupang, might be opening up political opportunities for domestic workers in urban Indonesia.

\section{References}

- $\quad$ Ally, S. (2010). From servants to workers: South African domestic workers and the democratic state. Scottsville, SA: University of KwaZulu-Natal Press.

- $\quad$ Anderson, B. (2000). Doing the dirty work? The global politics of domestic labour. London: Zed Books.

- $\quad$ Bapat, S. (2014). Part of the family? Nannies, housekeepers, caregivers and the battle for domestic workers' rights. New York: Ig Publishing.

- $\quad$ Castles, S. (2011). Migration, crisis and the global labour market. Globalizations, 8(3), 311-324.

- $\quad$ Chin, C. B. N. (1997). Walls of silence and late twentieth century representations of the foreign female domestic worker: The case of Filipina and Indonesian female servants in Malaysia. International Migration Review, 31(2), 353-385.

- $\quad$ Chin, C. B. N. (2003). Visible bodies, invisible work: State practices toward migrant women domestic workers in Malaysia. Asian and Pacific Migration Journal, 12(1-2), 49-73.

- Elmhirst, R. (2012). Methodological dilemmas in migration research in Asia: research design, omissions and strategic erasures. Area, 44(3), 274-281.

- $\quad$ England, K., \& Stiell, B. (1997). "They think you're as stupid as your English is": constructing foreign domestic workers in Toronto. Environment and Planning A, 29(2), 195-215.

- $\quad$ Forrest, R. (2008). Managing the Chaotic City? New Forms of Urban Governance and Challenge for East Asia In K. H. Mok \& R. Forrest (Eds.), Changing Governance and Public Policy in East Asia (pp. 287-302). Abingdon, Oxford: Routledge.

- Gastaldi, M. (2015). Domestic workers organisation as a tool to reduce social exclusion: The case of domestic workers organisation in Java. (Master en Science de la population et du développement), Universite Libre de Bruxelles, Bruxelles.

- $\quad$ Goldring, L., \& Landolt, P. (2011). Caught in the work-citizenship matrix: The lasting effects of precarious legal status on work for Toronto immigrants. Globalizations, 8(3), 325-341.

- Gray, M. (2004). The social construction of the service sector: institutional structures and labour market outcomes Geoforum, 35(1), 23-34.

- ILO. (2006). The regulation of domestic workers in Indonesia: Current laws, international standards and best practice 
- $\quad$ ILO. (2010). Decent work for domestic workers

- ILO. (2013). Domestic workers across the world: Global and regional statistics and the extent of legal protection

- IRIN News. (2009). Indonesia: Tough times for returning labour migrants (Jakarta, 14 May 2009). Retrieved 07 January 2016, from IRIN Humanitarian News and Analysis

- $\quad$ Painter, J. (2005). Urban citizenship and rights to the city

- $\quad$ Pratt, G. (1999). From registered nurse to registered nanny: Discursive geographies of Filipina domestic workers in Vancouver, B. C. Economic Geography, 75(3), 215-236.

- Pratt, G. (2012). Families apart: Migrant mothers and the conflicts of labor and love. Minneapolis, MN: University of Minnesota Press.

- Rudnyckyj, D. (2004). Technologies of servitude: governmentality and Indonesian transnational labor migration. Anthropological Quarterly, 77(3), 407-434.

- $\quad$ Sheppard, B. (2009). Workers in the shadows: Abuse and exploitation of child domestic workers in Indonesia

- $\quad$ Silvey, R. (2004). Transnational migration and the gender politics of scale: Indonesian domestic workers in Saudi. Singapore Journal of Tropical Geography, 25(2), 141-155.

- $\quad$ Silvey, R. (2006). Consuming the transnational family: Indonesian migrant domestic workers to Saudi Arabia. Global Networks, 6(1), 23-40.

- $\quad$ Tufts, S. (2007). Emerging labour strategies in Toronto's hotel sector: Toward a spatial circuit of union renewal. Environment \& Planning A, 39, 2383-2404.

- Varghese, L. (2006). Constructing a Worker Identity Class, Experience, and Organizing in Workers' Awaaz. Cultural Dynamics, 18(2), 189-211.

- Weix, G. G. (2000). Inside the home and outside the family: The domestic estrangement of Javanese servants. In K. M. Adams \& S. Dickey (Eds.), Home and hegemony: Domestic service and identity politics in South and Southeast Asia (pp. 137-156). Ann Arbor, MI: University of Michigan Press.

- Williams, C. P. (2007). Maiden voyages: Eastern Indonesian women on the move (Vol. 305). Singapore: Institute of Southeast Asian Studies (ISEAS).

- Yeoh, B. S. A., \& Huang, S. (1998). Negotiating public space: Strategies and styles of migrant female domestic workers in Singapore. Urban Studies, 35(3), 583-602.

- $\quad$ Yeoh, B. S. A., Huang, S., \& Gonzalez III, J. (1999). Migrant female domestic workers: Debating the economic, social and political impacts in Singapore. International Migration Review, 33(1), 114-136.

\footnotetext{
${ }^{1}$ Reported by IRIN News, "Indonesia: Tough times for returning labour migrants" (Jakarta, 14 May 2009). Accessed from http://www.irinnews.org on 07 January 2016.

${ }^{2}$ Reported by Business Insider Australia, "Indonesia wants to stop maids from working overseas after a nightmare incident was exposed in Hong Kong” (17 February 2015). Accessed from http://www.businessinsider.com.au/ on 07 January 2016.

${ }^{3}$ According to national chairperson Lita Anggraini, cited in Jakarta Post, "Modern-day slavery flourishing in RI, says report" (Jakarta, 19 November 2014). Accessed from http://www.thejakartapost.com on 14 January 2016.

${ }^{4}$ Found under "Practical information" on the blog Living in Indonesia - A site for expatriates (undated). Accessed from http://www.expat.or.id/ on 07 January 2016.
} 